\title{
The Existing Problems and Improvement Measure for Post Evaluation of Power Distribution Network Construction
}

\author{
Xian Cheng \\ School of Electrical and Engineering \\ ZhengZhou University \\ Zhengzhou City, China \\ e-mail: chengxian@zzu.edu.cn
}

\section{Jianwei Ma}

State Grid He Nan Electric Power Research Institute, Zhengzhou City, China

e-mail: majw@163.com

\author{
Wei Huang \\ He Nan En Pai High-Tech Group co., LTD \\ Zhengzhou City, China \\ e-mail: hwfred83@163.com \\ * Corresponding Author \\ Lianyao Jiao \\ School of Electrical and Engineering \\ ZhengZhou University \\ Zhengzhou City, China \\ e-mail: 122169042@qq.com
}

\begin{abstract}
With the State Grid Corporation of China pays more attention on distribution network, its investments are unceasingly enhanced. A plenty of distribution network construction projects are carried on gradually. At present, the evaluation of distribution network projects effect is relied mainly by manual evaluation. With so heavy workload and high blindness that it can't accurately reflect the project construction effect, and it already can't satisfy the needs of the development of distribution network. With development of distribution network, the acquired data can be constantly improved, which makes it possible to apply computer aided software to the post evaluation. In this paper, it first introduces the comprehensive evaluation and analysis software into the post evaluation work for distribution network projects, then put forwards the method of combining manual evaluations and computer aided software to reflect the project construction effect in post evaluation work. Finally, one construction project with detailed examples is analyzed.
\end{abstract}

Keywords-post evaluation; construction projects; computer aided software; comprehensive analysis; distribution network

\section{INTRODUCTION}

With the rapid development of social economy, people's living level is improved continuously, which causes the continued growth of electricity consumption, suburban district power supply pressure has emerged in power distribution network, the construction and development of power distribution network is facing new opportunities and challenges [1-4]. On one hand, the investment in distribution network continued to increase. On the other hand, lands for city construction lack gradually [5-8]. Distribution network equipment's layout remains difficult. The level of power supply and reliability of power supply needs to be improved. With the increasing importance of distribution network in recent years, the distribution network projects increased gradually. In order to construct the more appropriate distribution network, it need to evaluate the distribution network project, and summarize the construction achievements of the early, find out the weak links in the power distribution network, guiding the subsequent construction of power distribution network and enhance the ability of power supply.

\section{POST EVALUATION ON DISTRIBUTION NETWORK}

\section{A. The concept of post evaluation}

Post evaluation means that objective analysis the purpose, implementation process, function and influence of the completed project $[9,10]$. Identify the objectives of the project are accomplished and the main benefit indexes of the project are realized by the summary of project inspection. Post evaluation is the feedback link of project decision management; accurate, objective and scientific analyses the project effect basing on the current situation of power grid. The power grid project has been completed, the distribution network has been operated period of time, the effect and benefit of the project has been basically reflected, and the data of evaluation already completed at this time.

\section{B. Post-evaluation index system of distribution network}

Post evaluation index system of distribution network is a multi-objective and multi-level index system. It consists of four parts: reliability of power supply and quality of voltage, adaptability and coordination of developing, equipment utilization efficiency and the technical level of equipment, economic and social benefits. Fig. 1. shows that the basic logical structure of the post evaluation index system of distribution network. 


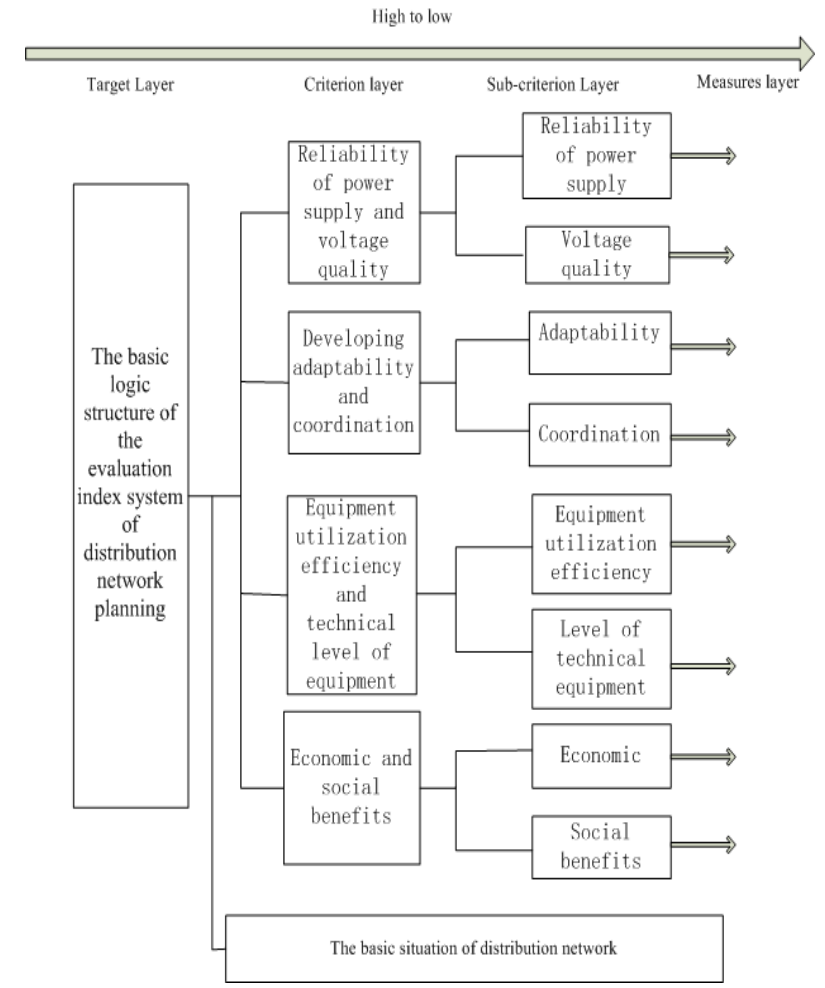

Figure 1. The basic logic structure of the post-evaluation index system of distribution network

Reliability of power supply and voltage quality: The basic requirement of distribution network is meeting the reliability of power supply and voltage quality. The reliability of power supply means security, reliable and unremitting supply electricity. It can be measured by customer average interruption frequency, customer average interruption time, power supply reliability rate and high-voltage equipment availability coefficient.

Adaptability and coordination of developing: The system of power grid is a big system and each project is required to adapt to the development of the power grid. Evaluation index of development adaptability mainly includes transformer $\mathrm{N}-1$ passing rate, line $\mathrm{N}-1$ passing rate, transformers capacity-load ratio and so on. The evaluation index of development coordination mainly includes transmission and distribution power grid substation capacity ratio, high voltage power distribution network substation capacity ratio and so on.

Utilization efficiency rate and technical level of equipment: Technical level of equipment largely reflects the success of the project in power grid projects. The utilization efficiency rate of equipment mainly includes load rate of transformer and line and their distribution. The evaluation index of the level of technical equipment mainly includes the proportion of non-oil circuit breakers, load tap device coverage, clean energy of distribution network access rate, the proportion of intelligent substation, distribution automation terminal coverage and so on.

Economic and societal benefits: Economy is the internal driving force to promote the continuous development of the power grid and social benefits is the basic purpose of the project. The evaluation index of economic mainly includes the cost of the unit line, the unit cost of substation capacity, power load of unit assets, the proportion of inputs and outputs, line loss rate and so on.
The societal benefits are reflected through the power quality and reliability of power supply.

\section{The evaluation characteristics of distribution network and its evaluation method}

Power grid construction project has its unique features, such as the project benefit reflected through the network and enterprise: the capital and technology of power grid enterprise is intensive, the level of equipment and technology is the important content of post evaluation, large amount of investment and so on. Post evaluation of power grid project also has its uniqueness: many evaluation indexes, post evaluation depends on the power grid network, strict environmental protection index and so on.

Post evaluation is usually use comparison method, logical framework analysis method and successful degree method. Considering the uniqueness of the post evaluation of the power grid, generally take the successful degree method. The method of successful degree is generally based on the implementation of all aspects of the project and through system standard or target judgment scale to assess the successful degree of project. Depending on the evaluation experts or expert group experience and comprehensive evaluate project, make a qualitative conclusion about the successfuldegree of the project.

\section{THE EXISTING PROBLEMS AND IMPROVEMENT MEASURE OF POST EVALUATION}

The amount of distribution network equipment and distribution area is large, and artificial evaluation only relies on experience to judge, blindness and uncertainties of project effect can't be avoided, and assessment cycle long influenced by human subjective factor. Only carried out qualitative analysis for construction projects, quantitative analysis can't be carried out. With the development of distribution network, manual method is time-consuming and laborious, and become increasingly unable to meet the needs of the development of dis tribution network.

With the construction of distribution automation system, a database of power network has been established and the basic data of distribution network equipment is more complete and accurate. It provides a convenient for the establishment of mathematical model and applying data mining to post evaluation. Based on the present situation of the distribution network, introducing comprehensive evaluation of distribution network analys is software into post evaluation can be effective to evaluate the current situation and effect of distribution network project, promote refinement and standardization of the evaluate work, promote develop healthy and effective distribution network. The establishment of the effective distribution network of the post evaluation system has important significance for realizing the scientific, guiding and controllability of distribution network construction. Now analyze the actual effect of somewhere in $10 \mathrm{kV}$ distribution network and evaluate its effect as a example.

\section{A. The basic situation of the power grid}

The area of power grid is 2182 square kilo meters, north and south long $67 \mathrm{~km}, 69 \mathrm{~km}$ wide from east to west, relying on the coal industry base advantage, abundant 
power resources, power with a total installed capacity of 260MW.As the pilot city of automation project of distribution network ,promote the distribution network modernization, equipment and technology is advanced, actively carry out the intelligent of distribution network, the database of power grid system is more perfectly ,the basic data of distribution network equipment is more complete and accurate. It lays the groundwork for the application with the comprehensive analysis software on distribution network. Realized the connection of the power grid database and analysis software, and it can import and export the data of power grid.

\section{B. Power source analysis}

As showed in Table I, there are two $220 \mathrm{kV}$ substations, six $110 \mathrm{kV}$ substations, forming single loop chain and radial power network. Importing the grid data into the analysis software, the results of data verification, the topology computation from the data table, to reflect the condition of equipment of the power source. Table I. shows the capacity of the substation is $854.5 \mathrm{MVA}$, power supply capacity at low voltage side is 562.75 MVA.

TABLE I. THE POWER SUPPLY POINT INFORMATION IN 2014

\begin{tabular}{|c|c|c|c|c|}
\hline $\begin{array}{c}\text { SUB } \\
\text { name }\end{array}$ & $\begin{array}{c}\text { Voltage } \\
\text { leveI } \\
\text { (kV) }\end{array}$ & $\begin{array}{c}\text { Capacity } \\
\text { (MVA) }\end{array}$ & $\begin{array}{c}\text { The potential } \\
\text { of additional } \\
\text { load (MVA) }\end{array}$ & $\begin{array}{c}\text { Average } \\
\text { load rate } \\
\text { \% }\end{array}$ \\
\hline $\begin{array}{c}110 \mathrm{kV} \\
\mathrm{XX}\end{array}$ & 110 & 80 & 21.5 & 75.3 \\
\hline $\begin{array}{c}110 \mathrm{kV} \\
\mathrm{XX}\end{array}$ & 110 & 31.5 & 1.5 & 65.6 \\
\hline $\begin{array}{c}110 \mathrm{kV} \\
\mathrm{XX}\end{array}$ & 110 & 80 & 3.6 & 76.3 \\
\hline $\begin{array}{c}110 \mathrm{kV} \\
\mathrm{XX}\end{array}$ & 110 & 80 & 23.5 & 70.8 \\
\hline $\begin{array}{c}110 \mathrm{kV} \\
\mathrm{XX}\end{array}$ & 110 & 63 & 13.9 & 68.8 \\
\hline $\begin{array}{c}110 \mathrm{kV} \\
\mathrm{XX}\end{array}$ & 110 & 40 & 2.3 & 75.8 \\
\hline $\begin{array}{c}220 \mathrm{kV} \\
\mathrm{XX}\end{array}$ & 220 & 150 & 30.8 & 56.9 \\
\hline $\begin{array}{c}220 \mathrm{kV} \\
\mathrm{XX}\end{array}$ & 220 & 330 & 56.3 & 69.8 \\
\hline
\end{tabular}

Based on statistical power source point, can obtain the statistics of outgoing line interval statistical of substation, to estimate whether substation outlet interval is constraint and whether there is the potential of expansion, as shown in Table II.

As show in Table III, according to the calculation of load capacity of transformer substation and the statistical analysis of topological relationships, we can analysis the problem that whether outgoing line interval and substation capacity is match, When the substation load rate is less than the maximum load rate that satisfy "n-1", the substation can pass "n-1" check.
TABLE II.

ANALYSIS OF OUTLET INTERVAL PROBLEM

\begin{tabular}{|c|c|c|c|c|c|}
\hline $\begin{array}{c}\text { SUB } \\
\text { name }\end{array}$ & $\begin{array}{c}\text { Volta } \\
\text { ge } \\
\text { le vel }\end{array}$ & $\begin{array}{c}\mathbf{1 0 k V} \\
\text { total } \\
\text { number } \\
\text { of } \\
\text { outgoing } \\
\text { line }\end{array}$ & $\begin{array}{c}\text { 10kV } \\
\text { outgoing } \\
\text { line } \\
\text { number } \\
\text { (use) }\end{array}$ & $\begin{array}{c}\text { 10k V } \\
\text { outgoing } \\
\text { line } \\
\text { number } \\
\text { (remai } \\
\text { ning) }\end{array}$ & $\begin{array}{c}\text { line } \\
\text { utiliz } \\
\text { ation } \\
\text { rate } \\
(\%)\end{array}$ \\
\hline $\begin{array}{c}110 \mathrm{kV} \\
\mathrm{XX}\end{array}$ & $\begin{array}{c}110 \\
\mathrm{kV}\end{array}$ & 13 & 12 & 1 & 92.31 \\
\hline $\begin{array}{c}110 \mathrm{kV} \\
\mathrm{XX}\end{array}$ & $\begin{array}{c}110 \\
\mathrm{kV}\end{array}$ & 7 & 5 & 2 & 71.43 \\
\hline $\begin{array}{c}110 \mathrm{kV} \\
\mathrm{XX}\end{array}$ & $\begin{array}{c}110 \\
\mathrm{kV}\end{array}$ & 4 & 4 & 0 & 100 \\
\hline $\begin{array}{c}110 \mathrm{kV} \\
\mathrm{XX}\end{array}$ & $\begin{array}{c}110 \\
\mathrm{kV}\end{array}$ & 6 & 4 & 2 & 66.67 \\
\hline $\begin{array}{c}110 \mathrm{kV} \\
\mathrm{XX}\end{array}$ & $\begin{array}{c}110 \\
\mathrm{kV}\end{array}$ & 12 & 11 & 1 & 91.67 \\
\hline $\begin{array}{c}220 \mathrm{kV} \\
\mathrm{XX}\end{array}$ & $\begin{array}{c}220 \\
\mathrm{kV}\end{array}$ & 11 & 9 & 2 & 100 \\
\hline $\begin{array}{c}220 \mathrm{kV} \\
\mathrm{XX}\end{array}$ & $\begin{array}{c}220 \\
\mathrm{kV}\end{array}$ & 2 & 2 & 0 & 100 \\
\hline
\end{tabular}

TABLE III.

ANALYSIS ON THE MATCHING PROBLEM BETWEEN OUTGOING LINE AND SUBSTATION CAPACITY

\begin{tabular}{|c|c|c|c|c|c|}
\hline $\begin{array}{c}\text { SUB } \\
\text { name }\end{array}$ & $\begin{array}{c}\text { Voltage } \\
\text { level } \\
\text { (kV) }\end{array}$ & $\begin{array}{c}\text { Capacity } \\
\text { constitutes } \\
\text { (MVA) }\end{array}$ & $\begin{array}{c}\text { SUB } \\
\text { Max. } \\
\text { load } \\
\text { rate } \\
(\%)\end{array}$ & $\begin{array}{c}\text { SUB } \\
\text { Max. } \\
\text { load } \\
\text { meet" } \\
\text { n-1" } \\
\text { check } \\
\text { rate } \\
(\%)\end{array}$ & $\begin{array}{c}\text { Meet" } \\
\text { n-1" } \\
\text { check }\end{array}$ \\
\hline $\begin{array}{c}110 \mathrm{kV} \\
\mathrm{XX}\end{array}$ & 110 & $2 \times 40$ & 87.29 & 65 & no \\
\hline $\begin{array}{c}110 \mathrm{kV} \\
\mathrm{XX}\end{array}$ & 110 & 31.5 & 65.9 & 55 & no \\
\hline $\begin{array}{c}110 \mathrm{kV} \\
\mathrm{XX}\end{array}$ & 110 & $2 \times 40$ & 71.1 & 60.3 & no \\
\hline $\begin{array}{c}110 \mathrm{kV} \\
\mathrm{XX}\end{array}$ & 110 & $2 \times 40$ & 83.22 & 65 & no \\
\hline $\begin{array}{c}110 \mathrm{kV} \\
\mathrm{XX}\end{array}$ & 110 & $2 \times 31.5$ & 65.5 & 68.1 & yes \\
\hline $\begin{array}{c}220 \mathrm{kV} \\
\mathrm{XX}\end{array}$ & 220 & 40 & 83.29 & 63.5 & no \\
\hline $\begin{array}{c}220 \mathrm{kV} \\
\mathrm{XX}\end{array}$ & 220 & 150 & 58.93 & 61 & yes \\
\hline
\end{tabular}

\section{Lines analysis}

\section{1) 'n-1'check}

The system of software can analyze whether the line meets"n-1"demand and whether the load needs to transfer to other lines. The transfer capacity is determined by methods of topological relationships."N-1" index largely reflects strong degree of distribution network. Table IV showed that one of these three lines did not have the support line. The remaining two support line did not pass the "n-1" check. 
TABLE IV.

ANALYSIS OF THE LINE TO MEET THE "N-1" DEMAND AND TRANSFER THE LOAD

\begin{tabular}{|c|c|c|c|c|c|c|}
\hline $\begin{array}{l}\text { Line } \\
\text { name }\end{array}$ & $\begin{array}{c}\text { SUB } \\
\text { name }\end{array}$ & $\begin{array}{l}\text { Pass } \\
\text { check }\end{array}$ & $\begin{array}{l}\text { line } \\
\text { segm } \\
\text { ents } \\
\text { num } \\
\text { ber }\end{array}$ & $\begin{array}{c}\text { Suppo } \\
\text { rt } \\
\text { line } \\
\text { name }\end{array}$ & $\begin{array}{c}\text { Supp } \\
\text { ort } \\
\text { line } \\
\text { mod } \\
\text { el }\end{array}$ & $\begin{array}{c}\text { Support } \\
\text { line } \\
\text { max. } \\
\text { load } \\
(\mathbf{k W})\end{array}$ \\
\hline $\begin{array}{c}10 \mathrm{kV} \\
\text { Bin\#3 } \\
0\end{array}$ & $\begin{array}{c}110 \mathrm{k} \\
\mathrm{V} \\
\text { substa } \\
\text { tion }\end{array}$ & no & 2 & no & no & no \\
\hline $\begin{array}{c}10 \mathrm{kV} \\
\text { Wei\# } \\
25\end{array}$ & $\begin{array}{c}110 \mathrm{k} \\
\mathrm{V} \\
\text { substa } \\
\text { tion }\end{array}$ & no & 2 & $\begin{array}{c}10 \mathrm{kV} \\
\text { Bin\#28 }\end{array}$ & $\begin{array}{l}\text { JKL } \\
\text { YJ- } \\
240\end{array}$ & $310 \mathrm{~kW}$ \\
\hline $\begin{array}{c}10 \mathrm{kV} \\
\text { \#6Jin } \\
\text { shan }\end{array}$ & $\begin{array}{c}110 \mathrm{k} \\
\mathrm{V} \\
\text { substa } \\
\text { tion }\end{array}$ & no & 5 & $\begin{array}{c}10 \mathrm{kV} \\
\text { Wei\#7 }\end{array}$ & $\begin{array}{l}\text { JKL } \\
\text { YJ- } \\
240\end{array}$ & $270 \mathrm{~kW}$ \\
\hline $\begin{array}{c}10 \mathrm{kV} \\
\text { south } \\
\# 7\end{array}$ & $\begin{array}{c}110 \mathrm{k} \\
\mathrm{V} \\
\text { substa } \\
\text { tion }\end{array}$ & no & 6 & $\begin{array}{c}10 \mathrm{kV} \\
\text { Wei\#6 }\end{array}$ & $\begin{array}{c}\text { JKL } \\
\text { YJ- } \\
185\end{array}$ & $500 \mathrm{~kW}$ \\
\hline
\end{tabular}

2) Transformation capacity analysis of segmented line As showed in Table V, we should improve the section switch and the contact switch on the distribution lines which are hanging excessive distribution capacity to avoid overly concentrated load. The more subsection number the less single piece of load users and blackout range.

TABLE V. ANALYSIS OF LINE SECTION CONNECTED WIIH THE PROBLEM OF TOO LARGE CAPACITY

\begin{tabular}{|c|c|c|c|c|}
\hline $\begin{array}{c}\text { Line } \\
\text { name }\end{array}$ & $\begin{array}{c}\text { SUB } \\
\text { name }\end{array}$ & $\begin{array}{c}\text { The } \\
\text { number of } \\
\text { large } \\
\text { section DT } \\
\text { capacity }\end{array}$ & $\begin{array}{c}\text { The } \\
\text { largest } \\
\text { number } \\
\text { of DT }\end{array}$ & $\begin{array}{c}\text { The maximum } \\
\text { capacity } \\
\text { of DT (k VA) }\end{array}$ \\
\hline $\begin{array}{c}10 \mathrm{kV} \\
\text { Hai\#29 }\end{array}$ & $\begin{array}{c}110 \\
\mathrm{kV}\end{array}$ & 18 & 5 & 630 \\
\hline $\begin{array}{c}10 \mathrm{kV} \\
\text { Jin\#5 }\end{array}$ & $\begin{array}{c}110 \\
\mathrm{kV}\end{array}$ & 14 & 3 & 2000 \\
\hline $\begin{array}{c}10 \mathrm{kV} \\
\text { Jin\#6 }\end{array}$ & $\begin{array}{c}110 \\
\mathrm{kV}\end{array}$ & 26 & 4 & 1250 \\
\hline $\begin{array}{c}10 \mathrm{kV} \\
\text { Leng\#15 }\end{array}$ & $\begin{array}{l}110 \\
\mathrm{kV}\end{array}$ & 31 & 8 & 800 \\
\hline
\end{tabular}

3) Analysis of load rate of transmission lines

If the load rate of distribution line is too high, it will influence the safe and stable operation of the power system. Therefore, we should focus on the transformation for overloaded lines. Transformation method including: (1) Replacing thicker diameter lines to reduce the operating current and increase the operation reliability and reduce the line loss. (2) To realized the purpose of the load transfer need to construct new lines under different power points. As showed in Table VI.
TABLE VI.

ANALYSIS OF LINE LOAD RATE

\begin{tabular}{|c|c|c|c|}
\hline Line name & $\begin{array}{c}\text { SUB } \\
\text { name }\end{array}$ & Line model & $\begin{array}{c}\text { Load } \\
\text { rate } \\
(\%)\end{array}$ \\
\hline $\begin{array}{c}10 \mathrm{kV} \\
\text { south\#20 }\end{array}$ & $\begin{array}{c}110 \mathrm{kV} \\
\text { substation }\end{array}$ & $\begin{array}{c}\text { YJV22- } \\
3 * 185, \text { JKLYJL- } \\
240, \text { JKLYJ-240,LGJ- } \\
240\end{array}$ & 66.9 \\
\hline $10 \mathrm{kV}$ south\#6 & $\begin{array}{c}110 \mathrm{kV} \\
\text { substation }\end{array}$ & $\begin{array}{c}\text { YJV22- } \\
3 * 185, \text { JKLYJL- } \\
240, \text { JKLYJ-240,LGJ- } \\
240\end{array}$ & 57.3 \\
\hline $10 \mathrm{kV}$ south\#9 & $\begin{array}{c}110 \mathrm{kV} \\
\text { substation }\end{array}$ & $\begin{array}{c}\text { YJLV22- } \\
3 * 185, \text { JKLYJL- } \\
240, \text { JKLYJ-240,LGJ- } \\
240\end{array}$ & 65.6 \\
\hline $10 \mathrm{kV}$ south\#7 & $\begin{array}{c}110 \mathrm{kV} \\
\text { substation }\end{array}$ & $\begin{array}{c}\text { YJLV22- } \\
3 * 300, \text { JKLYJL- } \\
240, \text { JKLYJ-240,LGJ- } \\
240\end{array}$ & 40.9 \\
\hline
\end{tabular}

4) Analysis of line trunk section

Trunk line is directly connected with the substation bus instead of connected with other lines. Trunk line requires higher reliability than the other lines, its operating mode is more flexible. We can get the sectional area of the trunk line by the trunk line type, as a bas is for the analysis of line trunk section. As showed in Table VII.

TABLE VII. ANALYSIS OF LINE TRUNK SECTION

\begin{tabular}{|c|c|c|c|c|c|c|}
\hline $\begin{array}{c}\text { Line } \\
\text { name }\end{array}$ & $\begin{array}{c}\text { SUB } \\
\text { name }\end{array}$ & $\begin{array}{c}\text { Trunk } \\
\text { line }\end{array}$ & \multicolumn{4}{|l|}{ Trunk section minimum line } \\
\hline $\begin{array}{c}10 \mathrm{kV} \\
\text { Hai\#29 }\end{array}$ & $\begin{array}{c}110 \\
\mathrm{kV}\end{array}$ & 1.25 & 2 & 1.25 & 100 & $\begin{array}{c}\text { JKLYJ } \\
\text { L-240 }\end{array}$ \\
\hline $\begin{array}{c}10 \mathrm{kV} \\
\text { Jin\#5 }\end{array}$ & $\begin{array}{c}110 \\
\mathrm{kV}\end{array}$ & 6.53 & $\begin{array}{c}\text { numb } \\
\mathrm{er}\end{array}$ & $\begin{array}{c}\text { Lengt } \\
\mathrm{km})\end{array}$ & $\begin{array}{c}\text { Propor } \\
\text { tion }\end{array}$ & Type \\
\hline $\begin{array}{c}10 \mathrm{kV} \\
\text { Jin\#6 }\end{array}$ & $\begin{array}{c}110 \\
\mathrm{kV}\end{array}$ & 3.33 & 17 & 3.33 & 100 & $\begin{array}{c}\text { JKLYJ } \\
\text { L-240 }\end{array}$ \\
\hline $\begin{array}{c}10 \mathrm{kV} \\
\text { Bin\#26 }\end{array}$ & $\begin{array}{c}110 \\
\mathrm{kV}\end{array}$ & 12.68 & 21 & 12.6 & 100 & $\begin{array}{c}\text { JKLYJ } \\
\text { L-240 }\end{array}$ \\
\hline
\end{tabular}

5) Summary of distribution line problem

Table VIII shows the summary of distribution line problem. 
TABLE VIII.

\begin{tabular}{|c|c|c|c|c|c|c|}
\hline $\begin{array}{c}\text { Line } \\
\text { name }\end{array}$ & $\begin{array}{c}\text { trunk } \\
\text { length } \\
\text { too } \\
\text { long }\end{array}$ & $\begin{array}{c}\text { trunk } \\
\text { Section } \\
\text { reaso } \\
\text { nable }\end{array}$ & $\begin{array}{c}\text { wiring } \\
\text { pattern } \\
\text { pass } \\
\text { "N-1" } \\
\text { check }\end{array}$ & $\begin{array}{c}\text { distrib } \\
\text { ution } \\
\text { capacity } \\
\text { reason } \\
\text { able }\end{array}$ & $\begin{array}{c}\text { line } \\
\text { load } \\
\text { rate } \\
\text { reas } \\
\text { ona } \\
\text { ble }\end{array}$ & $\begin{array}{c}\text { line } \\
\text { ope ra } \\
\text {-tion } \\
\text { life } \\
\text { too } \\
\text { long }\end{array}$ \\
\hline $\begin{array}{c}10 \mathrm{kV} \\
\text { Leng } \\
\# 15\end{array}$ & $\sqrt{ }$ & $\sqrt{ }$ & $\times$ & $\sqrt{ }$ & $\times$ & $\times$ \\
\hline $\begin{array}{c}10 \mathrm{kV} \\
\text { south } \\
\# 6\end{array}$ & $\times$ & $\sqrt{ }$ & $\times$ & $\sqrt{ }$ & $\times$ & $\times$ \\
\hline $\begin{array}{c}10 \mathrm{kV} \\
\text { Jin\#6 }\end{array}$ & $\sqrt{ }$ & $\times$ & $\times$ & $\sqrt{ }$ & & $\times$ \\
\hline $\begin{array}{c}10 \mathrm{kV} \\
\text { south } \\
\# 7\end{array}$ & $\times$ & $\sqrt{ }$ & $\times$ & $\sqrt{ }$ & $\times$ & $\times$ \\
\hline
\end{tabular}

IV. COMPREHENSIVE SCORE

Using the mathematical model and system server obtains the score of power grid project. Table IX shows the manual evaluation result and Table $\mathbf{X}$ shows the software evaluation result.

TABLE IX.

THE SCORE OF ARTIFICIAL METHODS

\begin{tabular}{|c|c|c|}
\hline Index & $\begin{array}{c}\text { Weighting } \\
\text { factor }\end{array}$ & Score \\
\hline $\begin{array}{c}\text { The quality and reliability of power } \\
\text { supply }\end{array}$ & 0.2 & 67.9 \\
\hline Operation safety & 0.2 & 74.5 \\
\hline The technical rationality & 0.2 & 76.5 \\
\hline $\begin{array}{c}\text { Maintenance level and economic } \\
\text { operation level }\end{array}$ & 0.15 & 79.6 \\
\hline The operation economy & 0.15 & 88.5 \\
\hline Distribution automation & 0.1 & 63 \\
\hline Total & 1 & 75.295 \\
\hline
\end{tabular}

The results of artificial method and software method are consistent. The software method can ensure that the results are accurate and quick.

TABLE $X . \quad$ THE SCORE OFCOMPREHENSIVE EVALUATION AND ANALYSIS SOFTWARE

\begin{tabular}{|c|c|c|}
\hline Index & $\begin{array}{c}\text { Weighting } \\
\text { factor }\end{array}$ & Score \\
\hline $\begin{array}{c}\text { The quality and reliability of power } \\
\text { supply }\end{array}$ & 0.2 & 77.9 \\
\hline Operation safety & 0.2 & 76.3 \\
\hline $\begin{array}{c}\text { The technical rationality } \\
\text { Maintenance level and economic } \\
\text { operation level }\end{array}$ & 0.2 & 82.5 \\
\hline The operation economy & 0.15 & 65.9 \\
\hline Distribution automation & 0.1 & 77.9 \\
\hline Total & 1 & 68.3 \\
\hline
\end{tabular}

\section{CONCLUSIONS}

With the improvement of city development level, the lines scale of urban medium voltage distribution network has been developing rapidly, expanding distribution network frame, load fast growth. But the equipment overload situation occurs frequently, the function and morphology of distribution network changed significantly at the same time. With distributed power be added to distribution network, the distribution network becomes an active network, the requirement of power supply is higher and higher. The way determining network vulnerabilities and the key of construction through manual analysis, has not met the development requirements of the modern distribution network. With the construction of the distribution network automation system, establish a complete power grid system database around the grid. The basic data of the distribution network equipment is relatively complete and accurate. Introducing the power distribution network comprehensive evaluation model and analysis method of data into the distribution network, the evaluation result of the benefit of the project can be more accurate. Through high-speed server docking database, realized automatically importing power grid data, can be fast accurately evaluate the effect of distribution network construction and effectively guide the construction of the follow-up.

\section{ACKNOWLEDGMENT}

This work was supported by National Nature Science Foundation of China (No.51407163, No.51477024) and China Postdoctoral Science Foundation (No. 2014M552012, No.2015T80778).

\section{REFERENCES}

[1] Pregelj A, Begovic M, Rohatgi A. "Recloser allocation for improved reliability of DG-enhances distribution networks," IEEE Trans Power Syst, vol 21, Mar. 2006, pp. 147-52.

[2] Zdraveski Vladimirl and Todorovski Mirko1, "Dynamic intelligent load balancing in power distribution networks," International Journal of Electrical Power and Energy Systems, vol 73, Dec.2015, pp. 157-162, 1, dio:10.1016/j.ijepes.

[3] Chen Shan, "Research on cost management system of distribution network construction projects based on data mining," China International Conference on Electricity Distribution, CICED, 2012, IEEE Computer Society, Sep. 2012, pp.1-7, doi: 10.1109/CICED.2012.6508454

[4] Gang Yao, "Research and Practice of Mesh-Networking Optimization for Power Supply by Complex Urban Distribution Network." Power System Technology, vol. 38, May. 2014, pp. 1297-1301, 10.13335/j.1000-3673.

[5] Tippachon W, Rerkpreedapong D. Multi objective optimal placement of switches and protective devices in electric power distribution systems using ant colony optimization. Electr Power Syst Res 2009;79(1):1171-8.

[6] Hashemi-Dezaki H, Askarian-Abyaneh H, Agheli A, Hosseinian SH, Mazlumi K,Nafisi H. "Optimized investment to decrease the failure rate of distribution lines in order to improve SAIF," The 4th international power engineering and optimization conf. (PEOCO2010), IEEE conference. June 2010, pp.

[7] Amanulla B, Chakrabarti S, Singh SN, "Reconfiguration of power distribution systems considering reliability and power loss," IEEE Trans Power Del, vol.27, 2,2012, pp.918-26.

[8] Atwa YM, El-Saadany EF, Salama MMA, Seethapathy R, Assam M, Conti S, "Adequacy evaluation of distribution system including wind/solar DG during different modes of operation," IEEE Trans Power Syst, vol.26, Apl, 2011,pp. 1945-52.

[9] Ochoa LF, Padilha-Feltrin A, Harrison GP, "Evaluating distributed generation impacts with a multiobjective index," IEEE Trans Power Del, vol. 21, 2006,pp. 1452-8.

[10] Billinton R, Bagen, Cui Y, "Reliability evaluation of small standalone wind energy conversion systems using a time series simulation model," Proc Inst Electr Eng, Gen, Transm, Distrib 2003, 96-100. 